\title{
Educational Benefits of Using Business Strategy Game (BSG) in Teaching and Learning Strategic Management
}

\author{
https://doi.org/10.3991/ijet.v14i07.9792 \\ Narentheren Kaliappen \\ Universiti Utara, Kedah, Malaysia \\ narentheren@uum.edu.my
}

\begin{abstract}
In today's education system develop students with high level of competencies and capabilities are very challenging task for every instructor. Graduates are anticipated to possess a wide-ranging of competencies such as critical thinking, problem solving and cognitive skills to enter the job market. The world economic trend is changing swiftly creating more necessities towards the students to develop the ability to be expert, flexible and adaptable. That requires a revolution of teaching practices and learning techniques. Business strategy game (BSG) serves as a realistic representation of the actual practices in a virtual setting, and use it to cultivate managerial skills mainly in decision making. This paper explored the educational benefits of the game based approach in teaching and learning strategic management at School of Business Management, Universiti Utara Malaysia (UUM). Approximately, 21 strategic management students participated in this research. Overall, the respondents provided a positive response about the benefit of the game based approach in teaching and learning process. In a nutshell, this study increases the understanding about the educational benefits of using BSG in teaching and learning strategic management for UUM undergraduates.
\end{abstract}

Keywords - Business strategy game, game based approach, strategic management

\section{Introduction}

In today's education system, developing students with high level of competencies and capabilities are very challenging task for every educator. Students are anticipated to possess a broad range of skills; critical thinking, problem solving and cognitive skills to manage efficiently in their future workplace. The global economy is changing rapidly, which demanding ever more skills, flexibility and adaptability among the students. Nonetheless, the conventional approaches and techniques used in teaching business and management skills are insufficient to handle the difficulty of modern organizations and unpredictable market dynamics [1] [2] [3]. In order to survive in these unpredictable marketplace, students' need an innovative teaching method for business education. Business games permit management students to experience the competitive dynamics, common tendencies, business encounters, interdependencies, 
and productivity drivers that are distinctive to an industry, and consequently, the business games are beneficial technique in the development of future human capital.

\subsection{Research question and objective}

This study explored the educational benefits of simulation game approach for teaching and learning strategic management offered by School of Business Management at Universiti Utara Malaysia (UUM). Approximately, 21 strategic management students participated in this research. The aim of this research is to present the findings on what are the educational benefits using a simulation game in teaching and learning strategic management for undergraduates at UUM. By answering this question, the researchers able to justify the simulation game as an innovative teaching method for business educators to teach a strategic management course.

\section{$2 \quad$ Literature Review}

\subsection{Business strategy game (BSG)}

Business Strategy Game (BSG) is a comprehensive online exercise game where the students run a footwear company in one-on-one rivalry against companies run by other classmates. Just as in the real world, companies strive in a global market, selling footwear's in four geographic regions; Europe-Africa, North America, Asia-Pacific, and Latin America. All features of the BSG are equivalent to the operative of the realworld footwear market, therefore permitting the students to think realistically and sensibly in determining what to do and acquire valuable practice in making a different business choice under situations that mirror real-world competitive conditions.

\subsection{Business strategy game as innovative teaching method}

Business simulation games combine the advantages of other methods, especially those focusing on student participation and decision-making. That is why they are considered as one of the most comprehensive methodologies that best grows the pedagogical skills of the users [4]. Students will learn to manage a business from the strategic management perspective, thus enlightening their ability for negotiation, as they will have to execute operations with other businesses and be able to formulate and implement competitive strategies. Hence, business games can be considered as a completed form of the case method to conduct a practical class.

Currently, the strategic management, teaching method is being criticized for being excessively emphasized on theoretical understanding rather than crafting strategic thinking, creativity and innovative skills [5]. Current hyper-competitive business environment requires highly talented human capitals to drive the business to achieve success. Apart from theoretical understanding, every strategic management student should possess additional skills, namely strategic thinking, decision-making skills, communication skills, and multidisciplinary knowledge. 
Therefore, strategic management scholars suggested that simulation based approach is one of the best methods to teach strategic management effectively, where the student have opportunities to expose the real business world.

\section{$3 \quad$ Methodology}

\subsection{Data sources and collection}

This research used quantitative research designs to understand the benefits of simulation based approach in teaching and learning strategic management. The students were divided into 5 groups consisting of 4 to 5 students in each group. Students required to respond to a questionnaire at the end of the course. The reason of the questionnaire is to assess the educational benefits of the students towards a BSG approach in teaching and learning Strategic Management. Since, this is a classroom research, the research used census as the method to study the population. So, the instructor selected 21 strategic management students who registered for the instructor's class for semester A162, 2016/2017 session.

\subsection{Instrumentation}

The instrumentation for this research adapted from [5] and [6]. The survey is divided into 2 parts, namely

- Demographic profiles

- Understand the educational benefits of simulation game

This research used 5 point likert scale from strongly disagree/ highly ineffective to strongly agree/ highly effective. The frequency analysis of this study is created on the percentage of the agreed statements.

\section{$4 \quad$ Findings}

The majority of respondents were female (90.48\%). $85.71 \%$ respondents were from semester 6 . About $52.38 \%$ of the respondents were Malays and $33.33 \%$ were Chinese. $47.62 \%$ of respondents were from Bachelor of Accounting (Hons), $19.05 \%$ were Bachelor of Muamalat (Hons) and 14.29\% were Bachelor of Business Administration (Hons). Table 1 clearly illustrated the demographic profiles. 
Table 1. Demographic Profile

\begin{tabular}{|c|c|c|}
\hline & Frequency & Percentage (\%) \\
\hline \multicolumn{3}{|l|}{ Gender } \\
\hline Male & 2 & 9.52 \\
\hline Female & 19 & 90.48 \\
\hline Total & 21 & 100 \\
\hline \multicolumn{3}{|l|}{ Semester } \\
\hline 9 & 1 & 4.76 \\
\hline 8 & 0 & 0 \\
\hline 7 & 1 & 4.76 \\
\hline 6 & 18 & 85.71 \\
\hline 5 & 1 & 4.76 \\
\hline Total & 21 & 100 \\
\hline \multicolumn{3}{|l|}{ Ethnicity } \\
\hline Malay & 11 & 52.38 \\
\hline Chinese & 7 & 33.33 \\
\hline Indian & 2 & 9.52 \\
\hline Somalia (International) & 1 & 4.76 \\
\hline Total & 21 & 100 \\
\hline \multicolumn{3}{|l|}{ Program } \\
\hline B.Acct. (Hons) & 10 & 47.62 \\
\hline B.Sc. AgriBus. Mgmt. (Hons) & 1 & 4.76 \\
\hline BBA (Hons) & 3 & 14.29 \\
\hline BBA (Log.\&Tpt.) (Hons) & 1 & 4.76 \\
\hline BHRM (Hons) & 2 & 9.52 \\
\hline BMA (Hons) & 4 & 19.05 \\
\hline Total & 21 & 100 \\
\hline
\end{tabular}

\subsection{Educational benefits}

The majority of the students provided positive response on the benefits of the business game in teaching and learning strategic management. The highest scores are acquiring new knowledge about business and management (100\%) and the exercise added a lot of realism to the strategic management course (100\%). Besides these two, students' also claimed that the simulation game is integrating the learning from functional areas (accounting, finance, strategy and marketing) $(95.22 \%)$, increase ability to identify problems $(85.72 \%)$, increase ability to solve practical problem $(85.72 \%)$ and increase ability to communicate clearly and effectively with peers $(85.72 \%)$.

Furthermore, students' also stated that this simulation game increases competency for planning business operations $(81 \%)$ and motivate people who work with them $(81 \%)$. The lowest score goes to increase ability to implement your decisions $(28.56 \%)$, increase confidence in work independently $(28.56 \%)$, add to ability to provide meaningful feedback to group members $(28.56 \%)$, experiment with new behaviour $(28.56 \%)$ and gain top management perspective on the operation of an organiza- 
tion $(28.56 \%)$. Table 2 shows the evidence that students' felt about the benefits of simulation game in teaching and learning strategic management.

Table 2. Education benefits

\begin{tabular}{|l|c|c|}
\hline \multicolumn{1}{|c|}{ Items } & Agreed statement & Ranking \\
\hline Acquire new knowledge about business and management & $100 \%$ & 1 \\
\hline $\begin{array}{l}\text { Integrate learning from functional areas (accounting, finance, strategy, mar- } \\
\text { keting etc.) }\end{array}$ & $95.22 \%$ & 2 \\
\hline Increase ability to identify problems & $85.72 \%$ & 3 \\
\hline $\begin{array}{l}\text { Add to understanding of how to seek and use information for problem solv- } \\
\text { ing. }\end{array}$ & $38.10 \%$ & 5 \\
\hline Learn how to seek and use information for problem solving & $38.10 \%$ & 5 \\
\hline Increase ability to solve practical problems & $85.72 \%$ & 3 \\
\hline Increase competence for planning business operations & $81.00 \%$ & 4 \\
\hline Increase ability to implement your decisions & $28.56 \%$ & 8 \\
\hline Increase confidence in work independently & $28.56 \%$ & 8 \\
\hline Become more aware of own feelings and beliefs & $38.09 \%$ & 6 \\
\hline Become more aware of the feelings and beliefs of others & $38.09 \%$ & 6 \\
\hline Add to ability to provide meaningful feedback to group members & $28.56 \%$ & 8 \\
\hline Motivate people who work with you & $81.00 \%$ & 4 \\
\hline Learn to help people resolve conflicts & $38.10 \%$ & 5 \\
\hline Increase ability to communicate clearly and effectively with peers & $85.72 \%$ & 3 \\
\hline Increase effectiveness as a participant in group problem solving & $33.33 \%$ & 7 \\
\hline Experiment with new behavior & $28.56 \%$ & 8 \\
\hline Learn new behavior & $33.33 \%$ & 7 \\
\hline Gain top management perspective on the operation of an organization & $28.56 \%$ & 8 \\
\hline Learn something important about yourself as a manager & $81.00 \%$ & 4 \\
\hline The exercise added a lot of realism to the strategic management course & $100.00 \%$ & 1 \\
\hline
\end{tabular}

\section{Discussion}

This paper presented an empirical test on the educational benefits of using a simulation game in teaching and learning strategic management. This paper shows that using simulation game in teaching and learning helps to acquire new knowledge about business and management. The students' felt that, this simulation game really gives realism to the strategic management course. Furthermore, this simulation game integrating learning from functional areas, which is really necessary when learning strategic management. The ability of identifying a problem, solving practical problem and communicate clearly with peers is very significant skills in strategic management because strategic management is entirely about decision-making. Thus, this simulation game explains about the application of strategic management concept and helps to translate this concept to practice. 


\subsection{Implications on teaching and learning}

BSG is a hands-on learning exercise that pulls together the lessons of previous courses, combines knowledge about running a company. Students get some beneficial knowledge and practice in measuring business risk, investigating industry and competitive situations, making decisions from a company's extensive outlook, think cleverly about a company's market position and developing strategies and reviewing them in light of shifting environments, and applying what they have learned in business courses. Essentially, BSG is firming up the preparation for a career in business and management areas.

In addition, the BSG makes the students' more competitive and have a lot of fun. Utilizing game based approach in teaching and learning strategic management course will create numerous benefits than the traditional teaching methods. This experimental learning approach will develop the cognitive perspective and essential motivational mechanism. The possible advancement in business simulations is enormous, and it will really enhance the students' participation.

Past studies suggested, that game based approach should not be looked as an alternate but game based approach is should be considered as a main pedagogy that will efficiently enrich the knowledge [7]. Without doubt, the application of the game based approach will strengthen strategic management, teaching and learning as well as produce highly skilled managers to the job market.

\section{Conclusion}

This paper suggested that game based approach is one of the best methods to teach strategic management effectively, where the students' have opportunities to expose the real business world. The usage of information technology is vital in planning new methods of teaching [8]. The use of simulation games as a pedagogic method is well established though its effective use is context-driven [9].Recent study found that computer based simulation games can be beneficial and may lead to better learning outcomes, skills acquisition as well as enhance students' team work through team based learning. [10]. Previously, lecturers tend to use face-to-face lectures and exam based evaluation. But, these methods brought some undesirable benefits among students, where they tend to perceive that general decision framework is applicable for any industry and situation. In a nutshell, this study increases the understanding about the educational benefits of using a simulation game (BSG) in teaching and learning strategic management for UUM undergraduates.

\section{$7 \quad$ Acknowledgement}

This research was funded by Universiti Teaching and Learning Centre (UTLC), Universiti Utara Malaysia under the Scholarship of Teaching \& learning (SoTL) grant. 


\section{References}

[1] Baker, E. L., \& O’Neil, H. F., Jr. (2002). Measuring problem solving in computer environments: current and future states. Computers in Human Behavior, 18, 609- 622. https://doi.org/10.1016/S0747-5632(02)00019-5

[2] Lehtinen, E. (2002). Commentary. Developing models for distributed problem--based learning: Theoretical and methodological reflection. Distance Education, 23(1), 109-117. https://doi.org/10.1080/01587910220124017

[3] Machuca, J. A. (2000). Transparent-box business simulators: An aid to manage the complexity of organizations. Simulation \& Gaming, 31(2), 230-239. https://doi.org/10.1177/ 104687810003100207

[4] Domingo, M. A. (2004): Los juegos de empresasobreges-tión de operacionesen la formaciónuniversitaria. Do-cumento de trabajo no publicado. Universidad de Se-villa.

[5] Abdullah, N. L., Hanafiah, M.H., \&Hashim, N.A. (2013). Developing creative teaching module: Business simulation in teaching strategic management. International Education Studies, 6 (6), 95-107. https://doi.org/10.5539/ies.v6n6p95

[6] Adobor, H., \&Daneshfar, A. (2006). Management simulations: Determining their effectiveness. Journal of Management Development, 25(2), 1151-168. https://doi.org/10.1108/ $\underline{02621710610645135}$

[7] Kendal, K. W., \& Harrington, R. J. (2003). Strategic management education incorporating written or simulation cases: An empirical test. Journal of Hospitality \& Tourism Research, 27(2), 143-165. https://doi.org/10.1177/1096348003027002001

[8] Aranda, D. A. (2007). Simulating reality for teaching strategic management. Innovations in Education and Teaching International, 44(3), 273-386. https://doi.org/10.1080/ 14703290701486662

[9] Loon, M., Evans, J., \&Kerridge, C. (2015). Learning with a strategic management simulation game: A case study. The International Journal of Management Education, 13(3), $227-$ 236. https://doi.org/10.1016/j.ijme.2015.06.002

[10] Bolívar-Ramos, M.-T., and Martínez-Salgueiro, A. (2018). Team-based learning in business courses: The application of case studies and simulation games. REIRE Revistad'InnovacióiRecercaenEducació, 11(2), 96-109.

\section{$9 \quad$ Author}

Narentheren Kaliappen is a senior lecturer at the School of International Studies, College of Law, Government and International Studies, Universiti Utara Malaysia (UUM). He holds a PhD (Strategic Management), master of Business Administration and bachelor of Business Administration from the Universiti Utara Malaysia. He also published quite a number of ISI/SCOPUS indexed journals, including Emerald, Inderscience and Sage publications in the field of strategic management and business administration in addition to presenting several papers at local and international conferences.

Article submitted 2018-10-31. Resubmitted 2018-12-13. Final acceptance 2018-12-15. Final version published as submitted by the authors. 